\title{
Cytochemical reactions of normal and neoplastic lymphocytes
}

\author{
F. R. DAVEY, S. J. HUNTINGTON, J. MACCALluM, AND J. M. MACMATH
}

From the Department of Pathology, State University of New York, Upstate Medical Center, Syracuse, New York 13210, USA

SUMMARY Rosetting and non-rosetting lymphocytes collected from normal individuals were stained for the presence of beta-glucuronidase, periodic-acid Schiff activity, gamma glutamyl transpeptidase, acid phosphatase, and alpha-naphthyl butyrate esterase. Lymphocytes which formed rosettes with sheep erythrocytes and non-rosette forming lymphocytes contained cytochemical reaction products for all five stains. Beta-glucuronidase $(\mathrm{P}<0.02)$ and acid phosphatase $(\mathrm{P}<0.01)$ were more frequently found in rosette forming lymphocytes. However, non-rosetting cells were more frequently periodic-acid Schiff positive $(\mathbf{P}<0.001)$. Gamma-glutamyl transpeptidase and alpha-naphthyl butyrate esterase were present equally in rosette and non-rosette forming lymphocytes. In addition, 33 non-Hodgkin's lymphomas were studied for cell surface markers and cytochemical reactions. In 17 of 19 B cell lymphomas, there was a paucity of lymphocytes containing beta-glucuronidase. However, in three of four $\mathrm{T}$ cell proliferations, there were numerous lymphoid cells positive for beta-glucuronidase. The periodic-acid Schiff and acid phosphatase reactions varied greatly within $\mathrm{B}, \mathrm{T}$, and null cell lymphomas and thus were of little diagnostic value in determining the cell of origin of these neoplastic lymphoid cells.

Lymphocytes are heterogeneous and can be separated into two subpopulations by a variety of immunological techniques (Aiuti et al., 1975). No morphological differences exist which permit the distinction of normal human thymic dependent lymphocytes ( $T$ cells) from bursa dependent lymphocytes (B cells) (Catovsky et al., 1974). Even scanning electron microscopy (Polliack and De Harven, 1975) by itself cannot be relied upon to differentiate the two lymphocyte subpopulations.

Recently, cytochemical studies in a variety of lymphoproliferative disorders suggested that betaglucuronidase was an enzyme marker for $T$ cells (Flandrin and Brouet, 1974; Flandrin and Daniel, 1974) and periodic-acid Schiff (PAS) a marker for B cells (Astaldi and Verga, 1957; Stein et al., 1972; Catovsky et al., 1974). Some investigators (Catovsky et al., 1974; Ritter et al., 1975) suggested that acid phosphatase was a $T$ cell marker in acutelymphocytic leukaemia. In contrast, others (Barr and Perry, 1976) have noted negative or weak acid phosphatase activity in normal human peripheral blood $T$ lymphocytes and moderate to strong reactivity in $\mathbf{B}$

Received for publication 8 December 1976 and null cells. In addition, other investigators (Szmigielski et al., 1965) have shown that $75 \%$ of human peripheral blood lymphocytes and $2-10 \%$ of bone marrow lymphocytes contain gamma-glutamyl transpeptidase activity. Since $T$ cells have a similar distribution in the blood and bone marrow, it seemed possible that gamma-glutamyl transpeptidase was also a cytochemical marker for $\mathrm{T}$ cells.

Li et al. (1973) demonstrated that monocytes and histiocytes, but not lymphocytes, contained nonspecific esterases which stained the cytoplasm diffusely when alpha-naphthyl butyrate was employed as substrate. Recently, we have noted that a small percentage of lymphocytes may demonstrate a focal deposit of alpha-naphthyl butyrate esterase.

Thus, this report describes an analysis of the betaglucuronidase, PAS, gamma-glutamyl transpeptidase, acid phosphatase, and alpha-naphthyl butyrate esterase cytochemical reactions in lymphocytes forming rosettes with sheep erythrocytes and in those non-rosetting lymphocytes collected from the peripheral blood of normal individuals. In addition, we describe our experience in defining the cytochemical reactions in 33 cases of non-Hodgkin's lymphoma analysed for the presence of cell surface markers. 
Material and methods

NORMAL PERIPHERAL BLOOD

Twenty millilitres of blood from 34 normal individuals were defibrinated with glass beads, and lymphocytes were separated from other blood elements on a column composed of a solution of sodium metrizoate and Ficoll ${ }^{R}$ (Pharmacia Chemical, Uppsala, Sweden). Lymphocytes were incubated with sheep erythrocytes in $25 \%$ fetal calf serum for 60 minutes at $37^{\circ} \mathrm{C}$, centrifuged at $200 \mathrm{~g}$ and incubated at $4^{\circ} \mathrm{C}$ overnight (Bach, 1973). After gentle resuspension, a portion of the sample was counted for rosetting lymphocytes (lymphocytes with three or more attached sheep erythrocytes) in a haemocytometer. The remainder of the cell suspension was spread on glass slides either directly or after cytocentrifugation and then air-dried (Hepburn and Ritts, 1974).

The accuracy of the cytocentrifuge lymphocyte rosette preparation was documented by the following control study. A comparison of percent rosette forming lymphocytes as enumerated with a haemocytometer $v$ cytocentrifuge preparation on duplicate blood samples from five normal healthy individuals and five patients with chronic lymphocytic leukaemia indicated a coefficient correlation of 0.9282. In addition, a paired $t$ test demonstrated that the means of the two methods were not significantly different $(0.7>\mathrm{P}>0.6)$.

Ten samples from normal individuals were stained for the presence of beta-glucuronidase (Lorbacher $e t$ al., 1967), PAS (Hayhoe and Flemans, 1969), and gamma-glutamyl transpeptidase (Szmigielski et al., 1965). In addition, 12 samples were stained for acid phosphatase (Li et al., 1970) and 12 different samples were stained for alpha-naphthyl butyrate esterase $(\mathrm{Li}$ et al., 1973) activity.

Two hundred rosette and non-rosette forming lymphocytes were enumerated for the presence of cytochemical reaction products. A cell was considered positive when at least one distinctly stained granule was apparent in the cytoplasm. The number of positive cells in rosetting lymphocytes were compared to those in non-rosetting lymphocytes by the use of the paired $t$ test.

\section{PATIENTS AND CONTROLS}

Lymph nodes and tissue, appropriate to establish a diagnosis, were obtained from 33 patients ultimately shown to have non-Hodgkin's lymphoma. Lymph nodes obtained from 24 patients without haematological malignancy served as controls.

PROCESSING OF TISSUE

All tissue was processed in the fresh state, and numerous touch preparations were made from a cut surface. A portion of each lymph node was fixed in :either Bouin's solution or $10 \%$ buffered formalin and processed for haematoxylin and eosin stained tissue section. The remainder of the node was used as the source of the lymphocyte suspension.

PREPARATION OF LYMPHOCYTE SUSPENSION COLLECTED FROM TISSUE

Portions of tissue were gently pressed through a fine stainless steel mesh and a cell suspension was washed three times in phosphate buffered saline solution at $\mathrm{pH} 7 \cdot 0$. Contaminating erythrocytes were removed by washing with Tris buffered ammonium chloride solution at $\mathrm{pH} 6 \cdot 2$. The cell suspension was gently centrifuged, and the sedimented cells were resuspended in Hank's balanced salt solution (Grand Island Biological Co, Grand Island, NY).

Lymphocytes were tested for their ability to form rosettes with sheep erythrocytes (Bach, 1973) as previously outlined. In addition, the presence of surface membrane immunoglobulins was measured (Papamichail et al., 1971). Fluorescein labelled monovalent antisera against $\gamma, \mu, \alpha, \delta$, and $\epsilon$ immunoglobulin heavy chains; albumin; $\kappa$ and $\lambda$ light chains; and fluorescein labelled polyvalent antisera against $\gamma, \mu$, and $\alpha$ heavy chains were obtained from Behring Diagnostics (Department of Hoechst Pharmaceuticals Inc, Somerville, NY 08876) and Meloy Laboratories Inc (Springfield, Virginia 22151).

\section{Results}

Blood collected from 34 normal individuals indi- ? cated that the mean concentration of leucocytes was $6.5 \pm 1.7 \times 10^{3}$ cells $/ \mu \mathrm{l}$, the average percent of lymphocytes was $35.3 \pm 11.0$ and the percent of rosette forming cells was $64 \cdot 2 \pm 9 \cdot 6$.

\section{CYTOCHEMISTRY OF ROSETTING AND}

NON-ROSETTING NORMAL LYMPHOCYTES

The cytochemical reactions for rosette forming and non-rosette lymphocytes are listed in Table 1. Betaglucuronidase and acid phosphatase were more frequently present in rosette than in non-rosette forming lymphocytes (Figs 1 and 2). In contrast, nonrosetting cells were more frequently positive with the periodic-acid Schiff reagent (Fig. 3). Gammaglutamyl transpeptidase and alpha-naphthyl butyrate : esterase were present equally in rosette and nonrosette forming lymphocytes (Fig. 4).

BENIGN LYMPH NODES

The cell surface marker data from lymphocyte suspensions and the results of cytochemical studies 
Table 1 Percent of normal lymphocytes with positive cytochemical reaction

\begin{tabular}{|c|c|c|c|c|c|c|c|c|c|}
\hline & Beta glucuronidase & \multicolumn{2}{|c|}{ Periodic-acid Schiff } & \multicolumn{2}{|c|}{$\begin{array}{l}\text { Gamma glutamyl } \\
\text { transpeptidase }\end{array}$} & \multicolumn{2}{|c|}{ Acid phosphatase } & \multicolumn{2}{|c|}{$\begin{array}{l}\text { Alpha naphthyl butyrate } \\
\text { esterase }\end{array}$} \\
\hline & $N R L$ & $R L$ & $N R L$ & $R L$ & $N R L$ & $R L$ & $N R L$ & $R L$ & $N R L$ \\
\hline $\begin{array}{l}\text { Mean } \pm \text { SD } \\
\text { RL } v \text { NRL* }\end{array}$ & $\begin{array}{c}75.1 \pm 15.657 .0 \pm 14.9 \\
0.01<P<0.02\end{array}$ & $\begin{array}{r}1 \cdot 5 \pm 1 \cdot 2 \\
P\end{array}$ & $\begin{array}{l}7.6 \pm 3.9 \\
0.001\end{array}$ & $\begin{array}{c}93.0 \pm 4 \cdot 2 \\
0.4<\end{array}$ & $\begin{array}{l}91.0 \pm 7.9 \\
P<0.5\end{array}$ & $\begin{array}{l}12.6 \pm 6.9 \\
0.005<P\end{array}$ & $\begin{array}{l}6.0 \pm 4.0 \\
<0.01\end{array}$ & $\begin{array}{r}8.6 \pm 8.4 \\
0.1<P\end{array}$ & $\begin{array}{l}4.0 \pm 4.5 \\
<0.2\end{array}$ \\
\hline
\end{tabular}

RL_rosetting lymphocyte; NRL-non-rosetting lymphocyte.

*RL $v$ NRL compared by paired $t$ test.

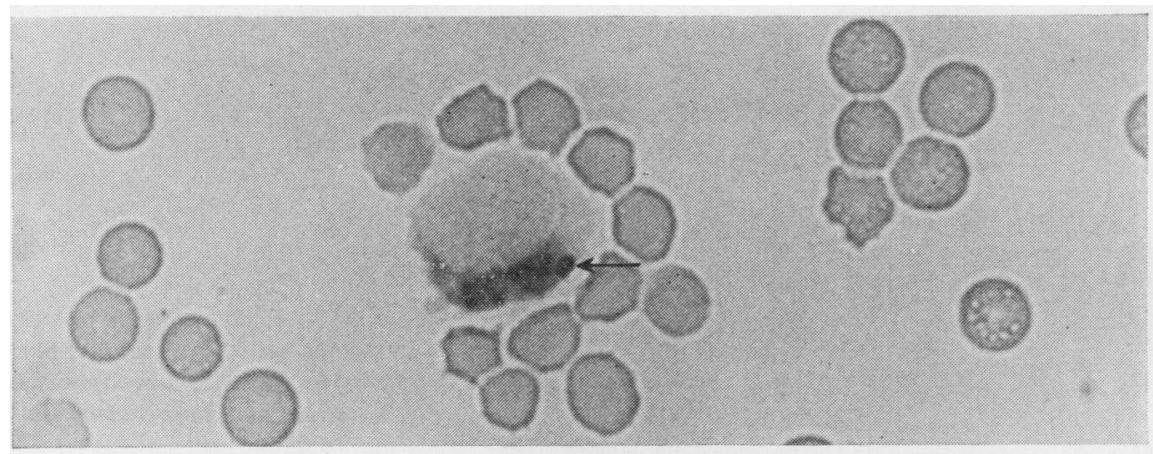

Fig. 1 Cytocentrifuge preparation of rosette forming lymphocytes stained for the presence of beta-glucuronidase. Positive cytoplasmic granules are noted by the arrow. $\times 1432$.

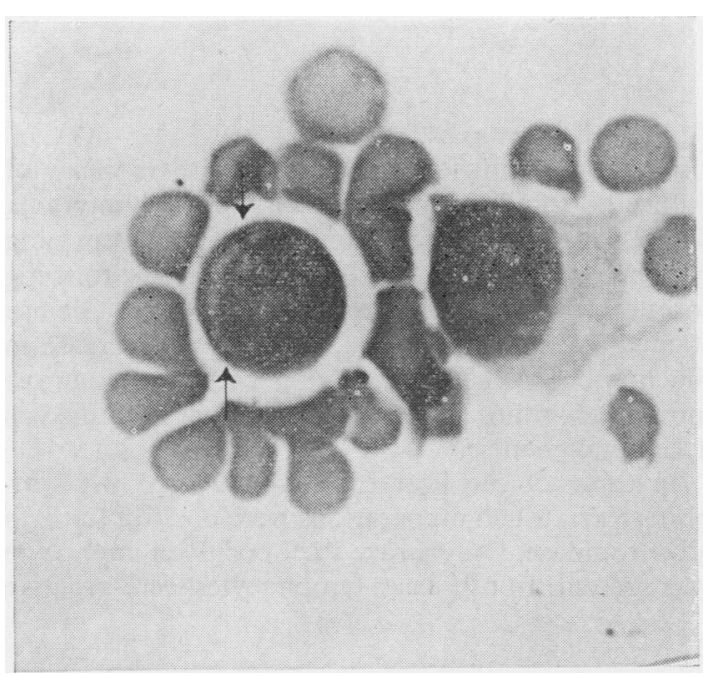

Fig. 2 Cytocentrifuge preparation of rosette forming lymphocytes stained for acid phosphatase. Two distinct acid phosphatase granules are noted in the rosetting lymphocyte while none is apparent in the non-rosetting lymphocyte. $\times 1432$.

obtained on touch preparations from 24 reactive lymph nodes are given in Table 2 . The mean number of rosette forming lymphocytes was $50 \cdot 8 \pm 15$ and the average number of cells with surface membrane immunoglobulin was $21 \cdot 0 \pm 13$. Fifty to eighty percent of lymphocytes from reactive lymph nodes demonstrated positive cytoplasmic staining with beta-glucuronidase and acid phosphatase. While most lymphocytes did not stain with PAS, 5-10\% showed diffuse, finely granulated PAS positive granules. Lymphocytes were negative for alphanaphthyl butyrate esterase. In contrast, macrophages exhibited intense cytoplasmic staining with beta-glucuronidase, acid phosphatase, and alphanaphthyl butyrate esterase, and moderate diffuse reaction with periodic-acid Schiff reagent.

\section{LYMPHORETICULAR MALIGNANCIES}

\section{$B$ cell proliferations}

Analysis of mononuclear surface markers on cell suspensions from neoplastic lymph nodes indicated that cases of undifferentiated lymphoma, histiocytic lymphoma, and lymphocytic lymphoma contained an increased number of cells bearing monoclonal immunoglobulin (Table 3). These lymphomas were classified as B cell proliferations.

When compared to reactive lymph nodes, neoplastic lymphoid cells observed on touch preparations from 17 of 19 cases classified as B cell malignancies showed a marked decrease in cells positive 
for beta-glucuronidase. Staining for PAS indicated that most cells were unreactive; only $5-10 \%$ of the cells exhibited PAS positive granules. Acid phosphatase reactions of touch preparations demonstrated a varied pattern of positivity. Some cases were devoid of acid phosphatase-containing cells while others showed cells with only weak cytoplasmic staining. Neoplastic cells were negative for alphanaphthylbutyrate esterase.

In contrast, the macrophages in these $19 \mathrm{~B}$ cell lymphomas and the remaining 14 lymphoid malignancies exhibited positive cytoplasmic staining for beta-glucuronidase, periodic-acid Schiff, acid phosphatase, and alpha-naphthyl butyrate esterase.
Fig. 3 Cytocentrifuge preparation of rosetteforming lymphocytes stained for periodic-acid Schiff activity. Note localisation of reaction product in non-rosetting lymphocytes but not in rosetting lymphocyte. $\times 1432$.

Fig. 4 Cytocentrifuge preparation stained for alpha naphthyl butyrate esterase. Reaction product is noted in rosetting and non-rosetting lymphocytes. $\times 1432$.

\section{$T$ cell proliferations}

One case of diffuse histiocytic and three cases of diffuse poorly differentiated lymphocytic lymphoma demonstrated increased numbers of rosette forming lymphocytes or abnormal lymphoid cells forming rosettes with sheep erythrocytes in Wright-Giemsa stained smears. In addition, there was a decrease in the number of cells containing surface membrane immunoglobulin. These four cases were identified as $\mathrm{T}$ cell malignancies.

In three of the four cases, $50-80 \%$ of the lymphocytes in touch preparations were positive for beta glucuronidase. Only a rare PAS positive lymphocyte was present. In two cases lymphocytes were negative

Table 2 Cytochemical and immunological cell markers in 24 reactive lymph nodes

\begin{tabular}{|c|c|c|c|c|c|c|}
\hline & $\begin{array}{l}\text { Percent rosette } \\
\text { forming cells }\end{array}$ & $\begin{array}{l}\text { Percent cells with } \\
\text { surface membrane } \\
\text { immunoglobulin }\end{array}$ & $\begin{array}{l}\text { Beta } \\
\text { glucuronidase }\end{array}$ & $\begin{array}{l}\text { Periodic-acid } \\
\text { Schiff }\end{array}$ & $\begin{array}{l}\text { Acid } \\
\text { phosphatase }\end{array}$ & $\begin{array}{l}\text { Alpha naphthyl } \\
\text { butyrate esterase }\end{array}$ \\
\hline $\begin{array}{l}\text { Lymphocytes } \\
\text { Macrophages }\end{array}$ & $50.8 \pm 15.0$ & $21 \cdot 0 \pm 13 \cdot 0$ & $\begin{array}{l}50 \%-80 \% \\
\text { Positive } \\
\text { Diffuse intense } \\
\text { stain }\end{array}$ & $\begin{array}{l}5 \%-10 \% \\
\text { Positive } \\
\text { Diffusely moderate } \\
\text { stain }\end{array}$ & $\begin{array}{l}50 \%-80 \% \\
\text { Positive } \\
\text { Diffuse moderate } \\
\text { to intense stain }\end{array}$ & $\begin{array}{l}\text { Negative } \\
\text { Diffuse intense } \\
\text { staining }\end{array}$ \\
\hline
\end{tabular}


Table 3 Cytochemical and immunological cell markers in non-Hodgkin's lymphoma

\begin{tabular}{|c|c|c|c|c|c|c|c|}
\hline Case & $\begin{array}{l}\text { Histopathological } \\
\text { diagnosis }\end{array}$ & $\begin{array}{l}\text { Percent } \\
\text { rosette-forming } \\
\text { cells }\end{array}$ & $\begin{array}{l}\text { Percent cells } \\
\text { with surface } \\
\text { membrane } \\
\text { immunoglobulin }\end{array}$ & $\begin{array}{l}\text { Beta } \\
\text { glucuronidase }\end{array}$ & $\begin{array}{l}\text { Periodic-acid } \\
\text { Schiff }\end{array}$ & $\begin{array}{l}\text { Acid } \\
\text { phosphatse }\end{array}$ & $\begin{array}{l}\text { Alpha-naphthyl } \\
\text { butyrate esterase }\end{array}$ \\
\hline \multicolumn{8}{|c|}{ B cell proliferations } \\
\hline 1 & DHL & 0 & $89 \cdot 0$ IgGk & Negative & $\begin{array}{l}10-15 \% \\
\text { Positive }\end{array}$ & $\begin{array}{l}>50 \% \text { Weakly } \\
\text { positive }\end{array}$ & Negative \\
\hline 2 & DHL & 1.4 & 96.0 IgMk & Negative & $\begin{array}{l}10 \% \\
\text { Positive }\end{array}$ & $\begin{array}{l}>50 \% \text { Weakly } \\
\text { positive }\end{array}$ & Negative \\
\hline 3 & DHL & $0 \cdot 1$ & 94.5 IgMk & Negative & $\begin{array}{l}\text { Rare } \\
\text { positive }\end{array}$ & $\begin{array}{l}>50 \% \text { Weakly } \\
\text { positive }\end{array}$ & Negative \\
\hline 4 & DHL & $5 \cdot 5$ & 82.0 IgMk & ND & $\begin{array}{l}\text { Rare } \\
\text { positive }\end{array}$ & Negative & Negative \\
\hline 5 & DHL & $6 \cdot 0$ & $84 \cdot 0 \operatorname{IgM} \lambda$ & $\begin{array}{l}>50 \% \\
\text { Positive }\end{array}$ & $\begin{array}{l}\text { Rare } \\
\text { positive }\end{array}$ & Negative & Negative \\
\hline 6 & DHL & $17 \cdot 2$ & $88 \cdot 0$ IgMk & Negative & Negative & $\begin{array}{l}>50 \% \text { Weakly } \\
\text { positive }\end{array}$ & Negative \\
\hline $\begin{array}{l}7 \\
8\end{array}$ & $\begin{array}{l}\text { UL } \\
\text { UL }\end{array}$ & $\begin{array}{l}1.0 \\
7.0\end{array}$ & $\begin{array}{l}40.0 \\
81.0 \text { IgMk }\end{array}$ & $\begin{array}{l}\text { Negative } \\
\text { Negative }\end{array}$ & $\begin{array}{l}\text { Negative } \\
\text { Negative }\end{array}$ & $\begin{array}{l}\text { Negative } \\
\text { Negative }\end{array}$ & $\begin{array}{l}\text { Negative } \\
\text { Negative }\end{array}$ \\
\hline 9 & UL & $29 \cdot 0$ & 82.0 IgMk & Negative & $\begin{array}{l}\text { Rare } \\
\text { positive }\end{array}$ & ND & $\begin{array}{l}\text { Rare focal } \\
\text { positive }\end{array}$ \\
\hline 10 & NMHLL & $33 \cdot 0$ & $31 \cdot 0$ IgMk & Negative & $\begin{array}{l}\text { Rare } \\
\text { positive }\end{array}$ & Negative & Negative \\
\hline 11 & NPDLL & $15 \cdot 5$ & $74 \cdot 5$ IgMk & Negative & $1 \%$ Positive & $\begin{array}{l}>50 \% \text { Weakly } \\
\text { positive }\end{array}$ & Negative \\
\hline 12 & NPDLL & $2 \cdot 8$ & $69 \cdot 0$ IgMk & Negative & $5 \%$ Positive & $\begin{array}{l}>50 \% \text { Weakly } \\
\text { positive }\end{array}$ & Negative \\
\hline $\begin{array}{l}13 \\
14\end{array}$ & $\begin{array}{l}\text { NPDLL } \\
\text { NPDLL }\end{array}$ & $\begin{array}{l}\text { ND } \\
57.0\end{array}$ & $\begin{array}{l}86.0 \text { IgMk } \\
20.0 \text { IgAk }\end{array}$ & $\begin{array}{l}\text { Negative } \\
\text { Rare positive }\end{array}$ & $\begin{array}{l}\text { Negative } \\
\text { Rare } \\
\text { positive }\end{array}$ & $\begin{array}{l}\text { Negative } \\
\text { Negative }\end{array}$ & $\begin{array}{l}\text { Negative } \\
\text { Negative }\end{array}$ \\
\hline $\begin{array}{l}15 \\
16 \\
17\end{array}$ & $\begin{array}{l}\text { NPDLL } \\
\text { NPDLL } \\
\text { NPDLL }\end{array}$ & $\begin{array}{l}39 \cdot 0 \\
35 \cdot 0 \\
46 \cdot 0\end{array}$ & $\begin{array}{l}34.0 \text { IgGk } \\
31.0 \text { IgM } \lambda \\
51.0 \text { IgMk }\end{array}$ & $\begin{array}{l}10 \% \text { Positive } \\
10 \% \text { Positive } \\
5 \% \text { Positive }\end{array}$ & $\begin{array}{l}\text { Negative } \\
5 \% \text { Positive } \\
\text { ND }\end{array}$ & $\begin{array}{l}\text { Negative } \\
5 \% \text { Positive } \\
>50 \% \text { Weakly } \\
\text { positive }\end{array}$ & $\begin{array}{l}\text { Negative } \\
\text { Negative } \\
\text { Negative }\end{array}$ \\
\hline 18 & DPDLL & $5 \cdot 5$ & $88 \cdot 0$ IgMk & $5 \%$ Positive & $\begin{array}{l}\text { Rare } \\
\text { positive }\end{array}$ & Negative & Negative \\
\hline 19 & DWDLL & $28 \cdot 0$ & 57.0 IgAk & $50 \%$ Positive & Negative & $\begin{array}{l}>50 \% \text { Weakly } \\
\text { positive }\end{array}$ & Negative \\
\hline \multicolumn{8}{|c|}{$T$ cell proliferations } \\
\hline 20 & DHL & $79 \cdot 5$ & $5 \cdot 0$ & $50 \%$ Positive & $\begin{array}{l}\text { Rare } \\
\text { positive }\end{array}$ & Negative & Negative \\
\hline 21 & DPDLL & $62 \cdot 0$ & $\mathbf{0}$ & $\begin{array}{l}\text { Rare } \\
\text { positive }\end{array}$ & $\begin{array}{l}\text { Rare } \\
\text { positive }\end{array}$ & Negative & Negative \\
\hline 22 & DPDLL & $75 \cdot 0$ & $4 \cdot 0$ & $>50 \%$ Positive & Negative & $\begin{array}{l}70 \% \text { Moderate } \\
\text { positive }\end{array}$ & Negative \\
\hline 23 & DPDLL & $42 \cdot 5$ & $9 \cdot 0$ & $85 \%$ Positive & Negative & $\begin{array}{l}30 \% \text { Moderate } \\
\text { positive }\end{array}$ & Negative \\
\hline \multicolumn{8}{|c|}{ Null cell proliferations } \\
\hline 24 & DHL & $\mathbf{3 3} \cdot \mathbf{0}$ & $7 \cdot 0$ & Rare positive & ND & $\begin{array}{l}>50 \% \text { Weakly } \\
\text { positive }\end{array}$ & Negative \\
\hline 25 & DMHLL & $2 \cdot 7$ & $8 \cdot 0$ & ND & $\begin{array}{l}\text { Rare } \\
\text { positive }\end{array}$ & $\begin{array}{l}>50 \% \text { Weakly } \\
\text { positive }\end{array}$ & Negative \\
\hline 26 & NMHLL & $48 \cdot 5$ & 5.0 & $\begin{array}{l}\text { Rare } \\
\text { positive }\end{array}$ & $\begin{array}{l}\text { Rare } \\
\text { positive }\end{array}$ & $20 \%$ Positive & Negative \\
\hline 27 & NPDLL & $67 \cdot 0$ & $8 \cdot 0$ & $\begin{array}{l}\text { Rare } \\
\text { positive }\end{array}$ & Negative & Negative & Negative \\
\hline 28 & DPDLL & $5 \cdot 0$ & $\mathbf{0}$ & Negative & Negative & Negative & Negative \\
\hline \multicolumn{8}{|c|}{ Lineage of proliferating cell uncertain } \\
\hline 29 & NMHLL & $40 \cdot 0$ & $15 \cdot 0 \mathrm{P}$ & $30 \%$ Positive & \multirow{5}{*}{$\begin{array}{l}\text { Rare } \\
\text { positive } \\
\text { Negative } \\
10-15 \% \\
\text { positive } \\
\text { Rare } \\
\text { positive } \\
\text { Rare } \\
\text { positive }\end{array}$} & \multirow{5}{*}{$\begin{array}{l}>50 \% \text { Weakly } \\
\text { positive } \\
\text { Negative } \\
15 \% \text { Weakly } \\
\text { positive } \\
>50 \% \text { Weakly } \\
\text { positive } \\
\text { Negative }\end{array}$} & Negative \\
\hline 30 & NMHLL & $38 \cdot 0$ & $15.0 \mathrm{P}$ & Negative & & & Negative \\
\hline 31 & $\begin{array}{l}\text { Immunoblastic } \\
\text { sarcoma }\end{array}$ & $73 \cdot 0$ & $13.5 \mathrm{P}$ & $10 \%$ Positive & & & Negative \\
\hline 32 & NPDLL & $15 \cdot 1$ & $47.0 \mathrm{P}$ & ND & & & Negative \\
\hline 33 & DWDLL & $38 \cdot 5$ & $21 \cdot 0 \mathrm{P}$ & $90 \%$ Positive & & & Negative \\
\hline
\end{tabular}

DHL = diffuse histiocytic lymphoma; UL = undifferentiated lymphoma; NMHLL = nodular mixed histiocytic lymphocytic lymphoma; NPDLL = nodular poorly differentiated lymphocytic lymphoma; DPDLL = diffuse poorly differentiated lymphocytic lymphoma; DWDLL = diffuse well differentiated lymphocytic lymphoma; ND = not done. 
for acid phosphatase, and two cases showed 30-70\% of lymphocytes positive for acid phosphatase. Alphanaphthyl butyrate esterase was negative in the proliferating lymphoid cells.

\section{Null cell proliferations}

Five cases were listed as null cell lymphomas. These neoplastic cells had either a marked decrease in all surface markers or the abnormal lymphoid cells were not observed to rosette with sheep erythrocytes on Wright-Giemsa smears concurrent with a marked decrease in cells with membrane immunoglobulin.

The cytochemical reactions in touch preparations from this group of lymphomas showed that the neoplastic lymphocytes were rarely positive for betaglucuronidase and PAS, occasionally reactive with acid phosphatase, and negative for alpha-naphthyl butyrate esterase.

\section{Neoplasms of uncertain lineage}

Five cases are listed as lymphoma of uncertain lineage. In these lymphoreticular malignancies the distribution of cell surface markers was not significantly different from those observed in cells from non-neoplastic lymph nodes.

The reaction product in lymphoid cells for betaglucuronidase and acid phosphatase varied greatly among the five cases. Lymphoid cells appeared negative for PAS reagent and alpha-naphthyl butyrate esterase.

\section{Discussion}

The concentration of leucocytes, percent of lymphocytes (Davidsohn and Henry, 1974), and percent of rosetting lymphocytes (Bach, 1973) in this study are similar to other normal published values.

Beta-glucuronidase, a lysosomal enzyme, has been demonstrated in granulocytes, erythroid cells, platelets, macrophages, and lymphocytes (Lorbacher et al., 1967). Tamanki and Essner (1969) found betaglucuronidase localisation in the diffuse lymphatic tissue of the human lymph node cortex and around the central arteriole of the splenic white pulp. Flandrin and Daniel (1974) found that betaglucuronidase activity was low in lymphocytes from patients with chronic lymphocytic leukaemia (a Bcell proliferation) and had increased activity in lymphocytes from patients with Sezary syndrome (a T-cell proliferation). In contrast, Brouet et al. (1976) could not substantiate an increase of beta-glucuronidase in cells from $\mathrm{T}$-derived acute lymphocytic leukaemia. However, Barr and Perry (1976), using normal $\mathrm{T}$-cell enriched populations, noted large blocks of cytoplasmic stain with beta-glucuronidase in more than $90 \%$ of $\mathrm{T}$ cells. The $\mathrm{B}$ cell fraction showed a variable pattern of multiple smaller positive reactions ranging from 10 to $76 \%$ of cells. Data음 presented in this current study demonstrated betaglucuronidase in both rosette and non-rosette form $-\frac{9}{+}$ ing normal lymphocytes and confirmed the observation that beta-glucuronidase is more frequently present in $T$ cells. In addition, there was a marked $\vec{D}$ decrease in the number of beta-glucuronidase positive cells in 17 of $19 \mathrm{~B}$ cell lymphoid malignancies and acs preservation of beta-glucuronidase positive cells in $\vec{\circ}$ three of four $T$ cell tumours.

In normal lymphocytes a positive PAS reaction $\vec{\omega}$ was noted more often in non-rosette forming lym-? phocytes than in rosette forming lymphocytes. How-o ever, when studying malignant lymphoid cells the ${ }_{0}$ PAS reaction was not sufficiently sensitive reliably to $-v$ differentiate B from $T$ cell neoplasms. Data from other investigators portrayed no uniform pattern. $\omega$ While some described a correlation between PAS은 reactivity and B cell lymphomas and leukaemias(Stein et al., 1972; Catovsky et al., 1974), others have noted a positive PAS reaction in Sezary cells, a $T^{<}$ cell proliferation (Taswell and Winkelmann, 1961; $\overrightarrow{0}$ Flandrin and Brouet, 1974). In addition, intense. $V$ PAS reactivity was observed in phytohaemagglutinin stimulated lymphocytes, suggesting the presence of PAS positive material in T cell blasts (Quaglino et al., 1962; Stathopoulos et al., 1974).

Szmigielski et al. (1965) demonstrated that gamma-闹 glutamyl transpeptidase is present in $75 \%$ of peripheral blood lymphocytes, a small percent of bone윽 marrow lymphocytes, $60 \%$ of plasma cells, $\frac{\Im}{\sqrt{3}}$ granulocytic cells, and normoblasts. Data reported in this study indicate that gamma-glutamyl transpeptidase is present equally in normal rosette form $\frac{0}{8}$ ing and non-rosette forming lymphocytes. Sinceo normal B cells could not be differentiated from? normal $T$ cells using the cytochemical reaction foro gamma-glutamyl transpeptidase, it was elected not to study its presence in the malignant lymphopro-음 liferative disorders.

In normal lymphocytes acid phosphatase was? noted more frequently in rosetting lymphocytes than in non-rosetting lymphocytes. This finding is in contrast to that of Barr and Perry (1976), who N demonstrated negative or weak acid phosphatase reaction in normal $T$ cells and moderate to strongo staining with normal $B$ and null cells. The dise cordance between the two observations regarding $\widetilde{\Phi}$ acid phosphatase activity in normal lymphocytes? cannot as yet be resolved. In the current study, the 0 presence of acid phosphatase in lymphocytes co!-우 lected from lymphoid tumours varied greatly and $\stackrel{\mathbb{Q}}{\mathcal{Q}}$ was interpreted not to be a reliable stain in differ-苂 entiating B from $T$ cell malignancies. Other reports $\sigma$ indicated that lymphocyte acid phosphatase activity 
in a variety of pathological conditions showed inconstant findings. Increased acid phosphatase activity has been observed presumably in $\mathrm{T}$ cells of acute lymphocytic leukaemias (Catovsky et al., 1974; Brouet et al., 1976) and in the atypical lymphocytes of infectious mononucleosis ( $\mathrm{Li}$ et al., 1970). Increased activity has also been demonstrated in cells of certain B cell proliferations, including macroglobulinaemia and multiple myelomas (Li et al., 1970). However, decreased acid phosphatase levels have been measured in chronic lymphocytic leukaemia (Douglas et al., 1973).

Alpha-naphthyl butyrate esterase was noted focally in only a small percentage of normal lymphocytes and was not observed to be present in significantly different levels in the two lymphocyte subpopulations. The great utility of this cytochemical reaction was in its ability to differentiate lymphocytes from macrophages (Li et al., 1973). Macrophages demonstrated intense diffuse cytoplasmic staining whereas only a small number of lymphocytes exhibited a focal small granular deposit. The lack of alpha-naphthyl butyrate esterase in the neoplastic cells collected from 33 cases of non-Hodgkin's lymphoma suggested that the proliferating cells were derived from lymphocytes and not from macrophages.

In summary, each cytochemical reaction was observed in rosette forming and non-rosette forming lymphocytes collected from normal individuals. However, beta-glucuronidase and acid phosphatase granules were present more frequently in rosette forming than in non-rosette forming normal lymphocytes. In contrast, a positive PAS reaction was more often observed in non-rosette forming lymphocytes. Gamma-glutamyl transpeptidase and alpha-naphthyl butyrate esterase were present equally in rosette and non-rosette forming lymphocytes. In neoplastic disorders, the beta-glucuronidase activity was decreased in 17 of $19 \mathrm{~B}$ cell proliferations and present in a normal number of lymphocytes from three of four $T$ cell tumours. The PAS and acid phosphatase reactions varied greatly and appeared not to be reliable markers in determining the lineage of neoplastic lymphoid cells.

\section{References}

Aiuti, F., Cerottini, J. C., Coombs, R. R. A., et al. (1975). International Union of Immunological Societies (IUIS report-July 1974. Identification, enumeration, and isolation of $B$ and $T$ lymphocytes from human peripheral blood. Clin. Immunol. Immunopath., 3, 584-597.

Astaldi, G. and Verga, L. (1957). The glycogen content of the cells of lymphatic leukaemia. Acta haemat. (Basel), 17, 129-135.

Bach, J. F. (1973). Evaluation of T-cells and thymic serum factors in man using the rosette technique. Transplant. Rev., 16, 196-217.

Barr, R. D. and Perry, S. (1976). Lysosomal acid hydrolases in human lymphocyte subpopulations. Brit. J. Haemat., 32, 565-572.

Brouet, J. C., Valensi, F., Daniel, M. T., Flandrin, G., Preud'Homme, J. L., and Seligmann, M. (1976). Immunological classification of acute lymphoblastic leukaemias: evaluation of its clinical significance in a hundred patients. Brit. J. Haemat., 33, 319-328.

Catovsky, D., Galetto, J., Okos, A., Miliani, E., and Galton, D. A. G. (1974). Cytochemical profile of B and $T$ leukaemic lymphocytes with special reference to acute lymphoblastic leukaemia. J. clin. Path., 27, 767-771.

Davidsohn, I. and Henry, J. B., eds. (1974). Todd Sanford Clinical Diagnosis by Laboratory Methods, p. 1388. 15th ed., W. B. Saunders: Philadelphia.

Douglas, S. D., Cohnen, G., König, E., and Brittinger, G. (1973). Lymphocyte lysosomes and lysosomal enzymes in chronic lymphocytic leukaemia. Blood, 41, 511-518.

Flandrin, G. and Brouet, J. C. (1974). The Sezary cell: Cytologic, cytochemical, and immunologic studies. Mayo Clin. Proc., 49, 575-583.

Flandrin, G. and Daniel, M. T. (1974). B-glucuronidase activity in Sezary cells. Scand. J. Haemat., 12, 23-31.

Hayhoe, F. G. J. and Flemans, R. J. (1969). An Atlas of Haematology Cytology, p 316. Wolf Medical Books: London.

Hepburn, B. and Ritts, R. E., Jr. (1974). Human T lymphocytes: assay method using permanently fixed slides. Mayo Clin. Proc., 49, 866-869.

Li, C. Y., Lam, K. W., and Yam, L. T. (1973). Esterases in human leukocytes. J. Histochem. Cytochem., 21, 112.

Li, C. Y., Yam, L. T., and Lam, K. W. (1970). Acid phosphatase isoenzyme in human leukocytes in normal and pathologic conditions. J. Histochem. Cytochem. 18, 473-481.

Lorbacher, P., Yam., L. T., and Mitus, W. J. (1967). Cytochemical demonstration of $B$-glucuronidase activity in blood and bone marrow cells. J. Histochem. Cytochem., 15, 680-687.

Papamichail, M., Brown, J. C., and Holborow, E. J. (1971). Immunoglobulins on the surface of human lymphocytes. Lancet, 2, 850-852.

Polliack, A. and De Harven, E. (1975). An interpretative review. Surface features of normal and leukemic lymphocytes as seen by scanning electron microscopy. Clin. Immunol. Immunopath., 3, 412-430.

Quaglino, D., Hayhoe, F. G. J., and Flemans, R. J. (1962). Cytochemical observations on the effect of phytohaemagglutinin in short-term tissue cultures. Nature (Lond.), 196, 338-340.

Ritter, J., Gaedicke, G., Winkler, K., Beckmann, H., and Landbeck, G. (1975). Possible T-cell origin of lymphoblasts in acid-phosphatase-positive acute lymphatic leukemia (Letter). Lancet, $2,75$.

Stathopoulos, G., Papamichail, M., Sheldon, P., Catovsky, D., Davies, A. J. S., Holborow, E. J., and Wiltshaw, E. (1974). Immunological studies in a case of T-cell leukaemia. J. clin. Path., 27, 851-859.

Stein, H., Lennert, K., and Parwaresch, M. R. (1972). 
Malignant lymphomas of B-cell type. Lancet, 2, 855-857. Szmigielski, S., Litwin, J., and Zupanska, B. (1965). Histochemical demonstration of gamma glutamyl transpeptidase activity in bone marrow and blood cells. J. clin. Path., 18, 244-246.

Tamaoki, N., and Essner, E. (1969). Distribution of acid phosphatase, $\beta$-glucuronidase and $\mathrm{N}$-acetyl- $\beta$-glucos- aminidase activities in lymphocytes of lymphatic tissues of man and rodents. J. Histochem. Cytochem., 17, 238-

Taswell, H. F. and Winkelmann, R. K. (1961). Sézary syndrome-a malignant reticulemic erythroderma. $J$. Amer. med. Ass., 177, 465-472.

\section{The June 1977 issue}

\section{THE JUNE 1977 ISSUE CONTAINS THE FOLLOWING PAPERS}

Factors affecting the value of a simple biochemical scheme for identifying Enterobacteriaceae: the reproducible recognition of biotypes J. G. BARR, REBECCA J. MAHOOD, AND K. P. W. CURRY

The API ZYM system in the identification of Gramnegative anaerobes D. THARAGONNET, P. R. SISSON, C. M. ROXBY, H. R. INGHAM, AND J. B. SELKON

Modification of the microimmunofluorescence test to provide a routine serodiagnostic test for chlamydial infection JOHN D. TREHARNE, S. DAROUGAR, AND BARRIE R. JONES

Isolation of Actinomyces viscosus from two patients with clinical infections B. L. RADFORD AND W. J. RYAN

Serum gentamicin assays of 100 clinical serum samples by a rapid $40^{\circ} \mathrm{C}$ Klebsiella method compared with overnight plate diffusion and acetyltransferase assays D. C. SHANSON AND CAROL HINCE

Estimation of serum gentamicin by quenching fluoroimmunoassay ELIZABETH J. SHAW, R. A. AMINA WATSON, J. LANDON, AND D. S. SMITH

Laboratory assessment of physical and chemical methods of preserving urine specimens P. G. WATSON AND B. I. DUERDEN

Cancer-associated proteins in effusion fluids $\mathbf{s} . \mathbf{N}$. BOOTH, G. LAKIN, P. W. DYKES, D. BURNETT, AND A. R. BRADWELL

Intracellular lysozyme and lactoferrin in myeloproliferative disorders D. Y. MASON
A new coagulation defect associated with a case of melanomatosis J. D. PHILLIPS AND M. J. O'SHEA

Cerebral involvement with disseminated intra- $\vec{c}$ vascular coagulation in intestinal disease F. P. RYAN, $\stackrel{\varrho}{<}$ W. R. TIMPERLEY, F. E. PRESTON, AND C. D. HOLDSWORTH

Light and electron microscopy study of capillaries in normal and inflammatory human synovial membrane ANTOINE DRYLL, JULIETTE LANSAMAN, PAULE CAZALIS, ANDRÉ P. PELTIER, AND STANISLAS DE SEZE

Macrophage infiltration of breast tumours: $a \stackrel{\varrho}{\not}$ prospective study I. LAUDER, W. AHERNE, J. STEWART, AND R. SAINSBURY

Immunohistochemical study of lichen planus SAMI SHOUSHA AND JOHN SVIRBELY

Evaluation of a teaching hospital necropsy service E. FIONA FOWLER, A. G. NICOL, AND I. N. REID

Aetiology of cirrhosis, hepatic fibrosis, and hepatocellular carcinoma W. K. BLENKINSOPP AND G. P. HAFFENDEN

\section{Technical methods}

Detection of beta lactamase activity of Haemophilus influenzae D. MCGHIE, P. D. CLARKE, T. JOHNSON, AND J. G. P. HUTCHISON

A rapid blood lactate assay using a centrifugal analyser and 3-acetylpyridine-adenine dinucleotide MARILYN P. EWEN AND A. R. HENDERSON

Letter to the Editor

Book reviews

Copies are still available and may be obtained from the PUBLISHING MANAGER, BRITISH MEDICAL ASSOCIATION, TAVISTOCK SQUARE, LONDON WC1H 9JR, price $£ 3 \cdot 00$, including postage 